\title{
Clinical, enzymatic, and molecular characterisation of a Portuguese family with a chronic form of $\mathrm{G}_{\mathrm{M} 2}$-gangliosidosis $\mathrm{B} 1$ variant
}

Instituto de Genética Médica Jacinto de Magalhães, Unidade de Enzimologia, Porto, Portugal M G Ribeiro

R A Pinto

A Fontes

H Ribeiro

E Pinto

M C Sá Miranda

Hospital S João, Serviço de Neurologia, Porto, Portugal T Sonin

M M Palmeira

Correspondence to: Dr Sá Miranda, Unidade de Enzimologia, Instituto de Genética Médica Jacinto de Magalhães, Praça Pedro Nunes 74, 4050 Porto, Portugal.

Received 27 September 1995

Revised version accepted for publication 28 November 1995

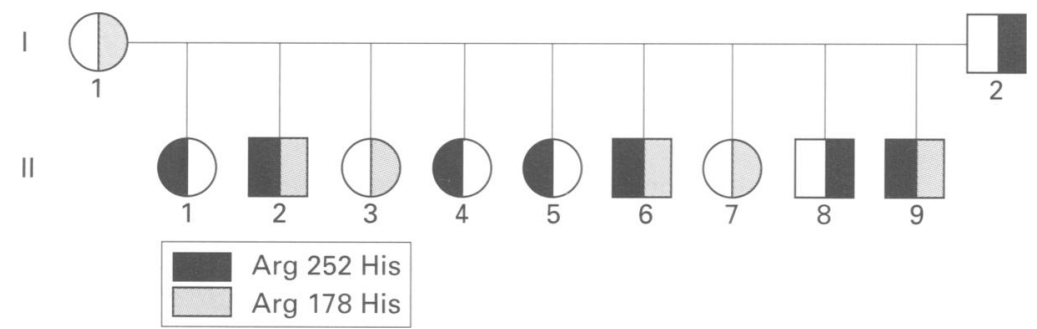

Figure 1 Pedigree of a family with a chronic form of the B1 variant.

E5

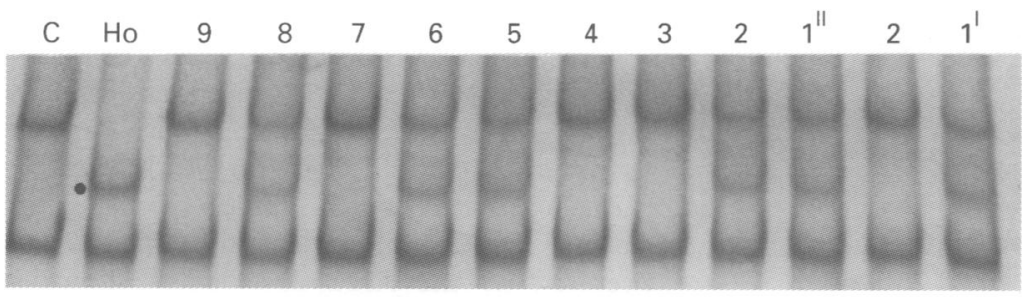

E7

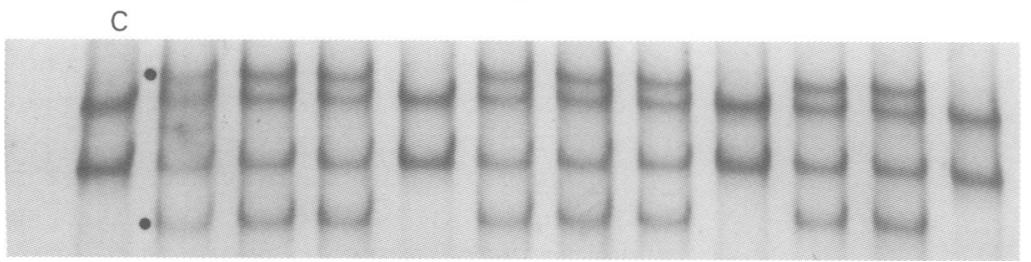

Figure 2 Single strand conformational polymorphism analysis of exons 5 and 7 of the HEXA gene. The exons and splicing junctions were amplified from $0 \cdot 1$ to $0 \cdot 3 \mu \mathrm{g}$ of genomic DNA, in a $100 \mu \mathrm{l}$ volume containing 0.2 mmoll of each nucleotide, 1.0 umoll primers, 2.5 units of Taq polymerase (Perkin-Elmer Cetus) in the buffer recommended by Cetus. Primers for each of the 14 HEXA exons were those described elsewhere. $A$ total of $10 \mu \mathrm{l}$ of PCR product was mixed with $5 \mu \mathrm{l}$ of $1 \% \mathrm{SDS}, 20 \mathrm{mmolll}$ EDTA (pH 9.0), and $10 \mu \mathrm{l}$ of formamide loading dye (95\% formamide, $20 \mu$ moll EDTA, 0.05\% bromophenol blue, $0.05 \%$ xylene-cyanol). The samples were denatured by heating at $96^{\circ} \mathrm{C}$ for 15 minutes, cooled on ice, and loaded onto $1 \times$ Hydrolink MDE gel. Electrophoresis was carried out at $4 W$ at room temperature for 17 hours. The conformational polymorphisms were visualised by silver staining according to a previously described procedure. ${ }^{10}$ The band shift owing to mutation is indicated by a dot. Lane C, control; lane $\mathrm{Ho}$, homozygote for the mutation $G 533 A$; E5, exon 5; E7, exon 7. form of the disease, who carry the transition G755A (Arg252His) on the second allele. This novel mutation is the first $B 1$ allele to be associated with an adult phenotype.

(f Med Genet 1996;33:341-343)

Key words: $\beta$-hexosaminidase; HEXA mutations; TaySachs disease.

B1 variant is a rare form of $\mathrm{G}_{\mathrm{M}_{2}}$-gangliosidosis characterised by the presence of a mutant Hex A ( $\alpha \beta$ heterodimer) with an altered substrate specificity owing to mutations in the catalytic site on the $\alpha$ subunit. ${ }^{12}$ This disease has been reported in patients with the subacute phenotype (with onset ranging from late infantile to juvenile), ${ }^{34}$ the majority of them carrying at least one Arg178His allele ${ }^{4-7}$ and having a Portuguese background..$^{5-7}$ To date, the chronic form of the disease has only been reported in three sibs of Portuguese origin but their genotype, to our knowledge, is not known. ${ }^{8}$

The pedigree of a Portuguese family studied in the present report is depicted in fig 1. Table 1 summarises the clinical characteristics of the three affected sibs. The molecular defects were shown by PCR-SSCP analysis (fig 2) followed by direct sequencing (fig 3 ). The patients were found to be compound heterozygotes for the mutations G533A and G755A. The genotype of the other family members was identified by testing both mutations by PCR-SSCP analysis (fig 2). The mutation G755A was confirmed by RFLP analysis with restriction enzyme NlaIII (fig 4). The mobility shifts corresponding to novel mutation G755A were not seen on SSCP analysis of 100 normal $\alpha$ chain genes (data not shown). Table 2 summarises the clinical, molecular, and biochemical data and compares it with previously published data on Portuguese B1 patients. ${ }^{13}$ In leucocytes from patients homozygous for the $\operatorname{Arg} 178 \mathrm{His}$ allele, the Hex A activity against 4MU-GlcNAc corresponded to about $50 \%$ of total hexosaminidase activity. In compound heterozygotes for this mutation, this activity seems to be dependent on the nature of the mutation present in the second allele. If the mutation produces no mature $\alpha$ subunit, such as in the classical infantile form of Tay-Sachs disease, the enzymatic activity will be that generated by one $\operatorname{Arg} 178 \mathrm{His}$ allele; therefore it must correspond to one half of the activity in 
Table 1 Clinical summary of the affected sibs with B1 variant

\begin{tabular}{|c|c|c|c|c|c|c|c|c|c|}
\hline Patient & $\begin{array}{l}\text { Age at } \\
\text { onset }(y)\end{array}$ & First symptom & $\begin{array}{l}\text { Language } \\
\text { retardation }\end{array}$ & Tremors & Speech loss & $\begin{array}{l}\text { Loss of } \\
\text { ability to } \\
\text { walk }\end{array}$ & $\begin{array}{l}\text { Pyramidal } \\
\text { signs }\end{array}$ & $E E G$ & $\begin{array}{l}\text { Present } \\
\text { age }(y)\end{array}$ \\
\hline $\mathrm{II} \cdot 2$ & 11 & $\begin{array}{l}\text { Behavioural } \\
\text { alterations }\end{array}$ & $\begin{array}{l}\text { After } 11 \\
\text { years }\end{array}$ & + & 25 years & 25 years & + & $\begin{array}{l}\text { Low amplitude } \\
\text { of basal rhythm }\end{array}$ & 32 \\
\hline II $\cdot 6$ & 5 & $\begin{array}{l}\text { Behavioural } \\
\text { alterations }\end{array}$ & $5-6$ years & 13 years & $\begin{array}{l}\text { Language } \\
\text { disturbance }\end{array}$ & $\begin{array}{l}\text { Not } \\
\text { observed }\end{array}$ & + & $\begin{array}{l}\text { No significant } \\
\text { abnormalities }\end{array}$ & 24 \\
\hline II $\cdot 9$ & 7 & $\begin{array}{l}\text { Behavioural } \\
\text { alterations }\end{array}$ & $7-8$ years & $\begin{array}{l}\text { Not } \\
\text { observed }\end{array}$ & $\begin{array}{l}\text { Language } \\
\text { disturbance }\end{array}$ & $\begin{array}{l}\text { Not } \\
\text { observed }\end{array}$ & + & $\begin{array}{l}\text { No significant } \\
\text { abnormalities }\end{array}$ & 15 \\
\hline
\end{tabular}

Table 2 Clinical, biochemical, and molecular data on Portuguese B1 variant patients

\begin{tabular}{|c|c|c|c|c|c|}
\hline \multirow[b]{3}{*}{ Case } & \multirow[b]{3}{*}{ Clinical phenotype } & \multirow[b]{3}{*}{ Genotype } & \multicolumn{3}{|c|}{ Hexosaminidase activity in leucocytes* } \\
\hline & & & \multicolumn{2}{|l|}{$4 M U-G l c N A c$} & \multirow{2}{*}{$\begin{array}{l}4 M U-G l c N A c 6 S \\
\operatorname{Hex} A\end{array}$} \\
\hline & & & Total Hex & $\%$ Hex $A$ & \\
\hline $\begin{array}{l}\mathrm{II} \cdot 2 \\
\mathrm{II} \cdot 6 \\
\mathrm{II} \cdot 9 \\
\mathrm{n}=10 \\
\mathrm{n}=1\end{array}$ & $\begin{array}{l}\text { Chronic } \\
\text { Chronic } \\
\text { Chronic } \\
\text { Subacute (juvenile onset) } \\
\text { Subacute (late infantile } \\
\text { onset) }\end{array}$ & $\begin{array}{l}\text { Arg178His/Arg252His } \\
\text { Arg178His/Arg252His } \\
\text { Arg178His/Arg252His } \\
\text { Arg178His/Arg178His } \\
\text { Arg178His/? }\end{array}$ & $\begin{array}{l}873 \\
785 \\
1086 \\
1045(610-1934) \\
1300\end{array}$ & $\begin{array}{l}56 \cdot 0 \\
53 \cdot 0 \\
57 \cdot 0 \\
61 \cdot 0(43 \cdot 0-66 \cdot 0) \\
24 \cdot 4\end{array}$ & $\begin{array}{l}7 \cdot 60 \\
5 \cdot 60 \\
8 \cdot 50 \\
2 \cdot 60(0 \cdot 59-7 \cdot 00) \\
4 \cdot 00\end{array}$ \\
\hline $\begin{array}{l}\mathrm{I} \cdot 2 \\
\mathrm{II} \cdot 1, \mathrm{II} \cdot 4, \mathrm{II} \cdot 5, \\
\mathrm{II} \cdot 8\end{array}$ & Normal & Arg252His heterozygous & $2133(1598-2985)$ & $59 \cdot 4(54 \cdot 3-63 \cdot 3)$ & $145(118-166)$ \\
\hline $\begin{array}{l}n=10 \\
n=4 \dagger \\
n=54\end{array}$ & $\begin{array}{l}\text { Normal } \\
\text { Normal } \\
\text { Normal }\end{array}$ & $\begin{array}{l}\text { Arg178His heterozygous } \\
\text { Tay-Sachs disease carriers }\end{array}$ & $\begin{array}{l}1846(1549-2266) \\
1396(1070-1714) \\
1580(967-2294)\end{array}$ & $\begin{array}{l}75 \cdot 0(68 \cdot 0-80 \cdot 0) \\
55 \cdot 7(47 \cdot 8-60 \cdot 0) \\
85 \cdot 0(88 \cdot 1-91 \cdot 0)\end{array}$ & $\begin{array}{l}112(96 \cdot 0-150) \\
140(122-155) \\
260(128-319)\end{array}$ \\
\hline
\end{tabular}

* The hexosaminidase activity was determined as previously described. ${ }^{11}$ Total Hex, hexosaminidase activity (nmol/h/mg protein) determined against the neutral synthetic substrate; \% Hex A, activity of the main peak eluted during $\mathrm{NaCl}$ gradient expressed as $\%$ of total 4MU-GICNAc revovered activity after ion-exchange chromatography on DEAE-cellulose; Hex A, hexosaminidase A activity (nmol/h/mg protein) determined against the sulphated synthetic substrate which was further purified as previously described. ${ }^{12}+$ Enzymatic data published in a previous report. ${ }^{11}$

C

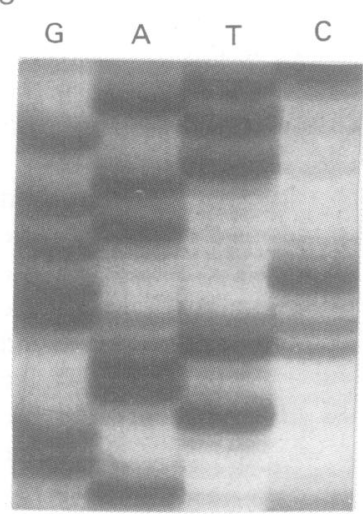

E5

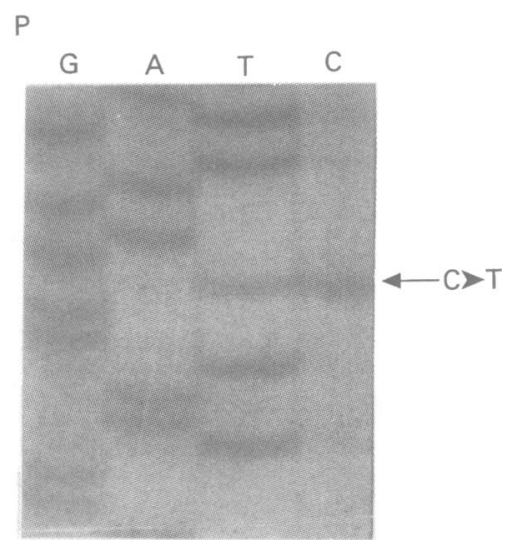

E7
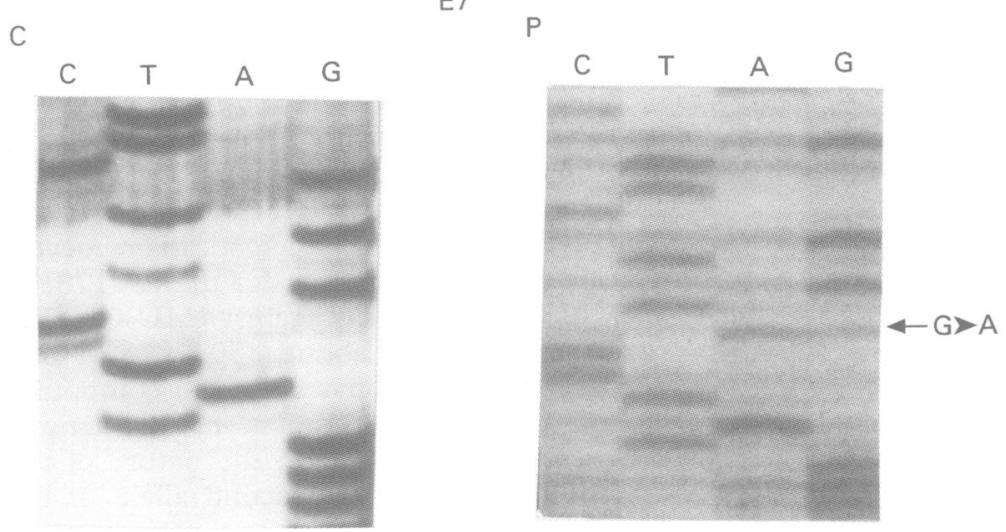

Figure 3 Sequence analysis of PCR samples. The segment of genomic DNA with an altered SSCP pattern was subjected to asymmetrical amplification, using the temperature profile of symmetrical PCR. The asymmetrical product was further purified and directly sequenced. The relevant portion of the sequence is shown. E5, exon 5 (antisense strand); $E 7$, exon 7 (sense strand); $C$, control; $P$, patient. homozygous patients. However, if the mutation is compatible with the synthesis of a mature protein with the enzymological characteristics of B1 variant, with residual activity against the synthetic unsulphated substrate, the Hex A activity is expected to be correspondingly higher. The Arg252His substitution, resulting from the mutation $\mathrm{G} 755 \mathrm{~A}$, occurs at conserved amino acids in human $\beta$ chain, ${ }^{14}$ the $\alpha$ and $\beta$ chain from mouse, ${ }^{15}$ and the hexosaminidase polypeptide from Dictyostelium discoideum. ${ }^{16}$

The clinical phenotype of patients with the substitution Arg178His and Arg252His in respective alleles is less severe than that observed for Arg178His homozygotes. Assuming that the clinical phenotype depends on enzymatic residual activity against ganglioside $G_{M 2}$ in vivo, ${ }^{17}$ it can be predicted that the Hex A generated by the Arg252His allele shows a higher intralysosomal residual activity than that generated by the Arg178His allele. Therefore it is likely that patients who have at least one Arg252His allele would have a chronic phenotype, irrespective of the nature of the mutation present in the other allele.

The majority of B1 mutations described in published reports occurred at codon 178, in which arginine is replaced by histidine, ${ }^{18}$ cysteine,${ }^{4}$ or leucine. ${ }^{9}$ The identification of another mutation also in one arginine codon points to the role of this positively charged amino acid in the catalytic domain of the $\alpha$ subunit. On the other hand, $\operatorname{Arg} 252$ is 74 amino acids from Arg178 in the coding sequence. Although the nature of the replaced amino acid is similar they might have different effects on the disruption of the tertiary structure of the catalytic domain of the protein. 


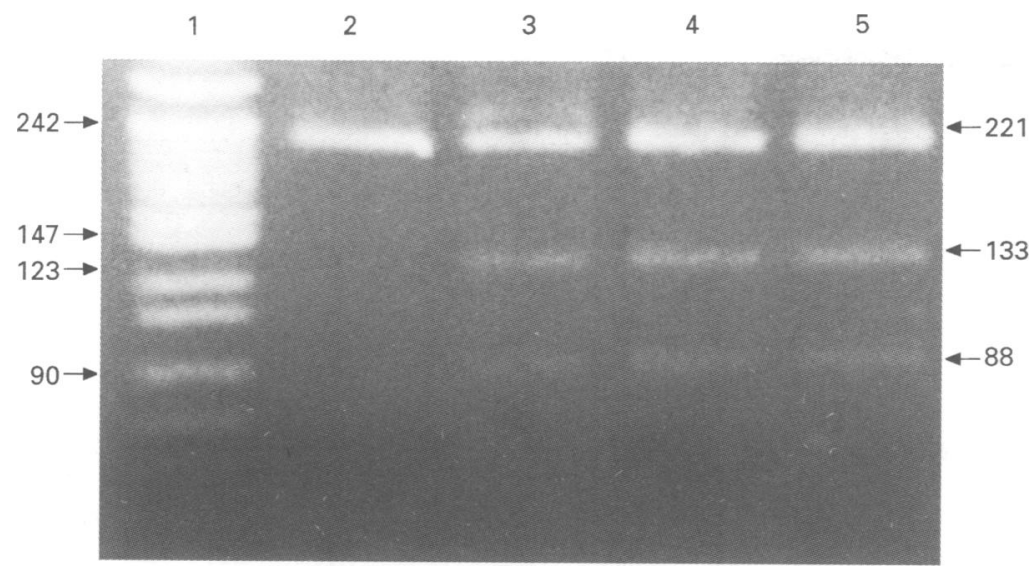

Figure 4 Confirmation of $G 755 A$ mutation by restriction analysis of amplification product with NlaIII (5'CATG $\left.\downarrow 3^{\prime}\right)$. About 100-200 ng of the amplified fragment encompassing exon 7 was digested overnight at $37^{\circ} \mathrm{C}$ with 15 units of NlaIII and the products analysed by electrophoresis on 3\% Nusieve 3:1 agarose gel. The DNA from the wild type allele will not be hydrolysed by NlaIII and the digestion yields a fragment of $221 \mathrm{bp}$. The mutant allele will be cleaved into two fragments of $133 \mathrm{bp}$ and $88 \mathrm{bp}$. DNA from the subjects who are heterozygous for the mutation will yield both intact and digested fragments. Lane 1, pBR322/MspI digest; lane 2, control; lane 3, subject II 2 ; lane 4, subject II.6; lane 5, subject II.9.

This work was partially supported by grant $\mathrm{BD} / 3010 / 94$ from JNICT (Portugal)

1 Kytzia HJ, Hinnrichs U, Maire I, Suzuki K, Sandhoff K. Variant of GM2-gangliosidosis with hexosaminidase A having a severely changed substrate specificity. EMBO $\mathcal{f}$ $1983 ; 2: 1201-5$

2 Kytzia HJ, Sandhoff K. Evidence for two different active sites on human $\beta$-hexosaminidase $A$. Interaction of GM2 activator protein with $\beta$-hexosaminidase A. $7 \mathrm{Biol}$ Chem 1985;260:7568-72.

3 Maia M, Alves D, Ribeiro G, Pinto R, Sá Miranda MC. Juvenile GM2 gangliosidosis variant B1: clinical and biochemical study in seven patients. Neuropediatrics 1989;21:
4 Tanaka A, Ohno K, Sandhoff K, et al. GM2-gangliosidosis Bl variant: analysis of $x$-hexosaminidase gene abnormalities in seven patients. Am f Hum Genet 1990;40 329-39.

5 Suzuki K, Vanier T. Biochemical and molecular aspects of late-onset GM2-gangliosidosis: B1 variant as prototype. Dev Neurosci 1991;13:288-94.

6 Akli S, Bone J, Sandhoff K, et al. Collaborative study of the molecular epidemiology of Tay-Sachs disease in Europe. Eur f Hum Genet 1993;1:229-38.

7 Dos Santos MR, Tanaka A, Sá Miranda MC, Ribeiro MG, Maia M, Suzuki K. GM2-gangliosidosis B1 variant: analysis of $\beta$-hexosaminidase $x$-gene mutations in 11 patients from a defined region in Portugal. Am $\mathcal{F}$ Hum Genet 1991; 49:886-90.

8 Specola N, Vanier MT, Goutières F, Mikol J, Aicardi J. The juvenile and chronic forms of GM2 gangliosidosis: clinical and enzymatic heterogeneity. Neurology 1990;40:145-50.

9 Triggs-Raine BL, Akerman BR, Clarke JTR, Gravel RA Sequence of DNA flanking the exons of the HEX A gene and identification of mutations in Tay-Sachs disease. $A m$ f Hum Genet 1991;49:1041-54.

10 Budowle B, Chakraborty R, Giusti AM, Eisenberg AJ, Allen RC. Analysis of the VNTR locus DIS 80 by the PCR followed by high-resolution PAGE. Am $\mathcal{F}$ Hum Genet 1991; 48:137-44.

11 Ribeiro MG, Pinto R, Sá Miranda MC, Suzuki K. TaySachs disease: intron 7 splice junction mutation in two Portuguese patients. Biochim Biophys Acta 1995;1270:4451.

12 Beccari I, Emiliani C, Hosseini R, Orlachio A, Stirling JL. Intermediate forms of human $\beta-\mathrm{N}$-acetylhexosaminidase lack activity towards 4-methylumbelliferyl- $\beta$-N-acetylglucosaminidase-6-sulphate. Biochem f 1987;244:801-4.

13 Ribeiro MG, Pinto RA, Dos Santos MR, Maia M, Sá Miranda MC. Biochemical characterization of $\beta$-hexosaminidase in different biological specimens from eleven patients with GM2 gangliosidosis B1 variant. F Inher Metab Dis 1991;14:715-20.

14 Myerowitz R, Piekarz R, Neufeld EF, Shows TB, Suzuki $K$. Human $\beta$-hexosaminidase $\alpha$ chain: coding sequence and homology with the $\beta$ chain. Proc Natl Acad Sci USA 1985;82:7830-4.

15 Yamanaka S, Johnson ON, Norflus F, Boles DJ, Proia RL. Structure and expression of the mouse $\beta$-hexosaminidase genes, Hexa and Hexb. Genomics 1994;21:588-96.

16 Graham TR, Zassenhaus HP, Kaplan A. Molecular cloning of the cDNA which encodes $\beta-\mathrm{N}$-acetylhexosaminidase A from Dictyostelium discoideum. $\mathcal{F}$ Biol Chem 1988;263: A from $D$.

17 Conzelmann E, Sandhoff K. Biochemical basis of late-onset neurolipidosis. Dev Neurosci 1991;13:197-204.

18 Ohno K, Suzuki K. Mutations in GM2-gangliosidosis B1 variant. $\mathcal{f}$ Neurochem $1988 ; 50: 316-8$. 